\title{
Learning Design
}

\section{Tilgange, cases og karakteristika}

\author{
Nina Bonderup Dohn, Syddansk Universitet \\ Mikkel Godsk, Aarhus Universitet \\ Lillian Buus, Via University College
}

\begin{abstract}
Feltet Learning Design har de seneste år inspireret adskillige uddannelsesudviklingsprojekter på de videregående uddannelser i Danmark. Dette er bl.a. synliggjort gennem to numre af Tidsskriftet Læring og Medier (LOM) med dette fokus i 2016. Imidlertid eksisterer der divergerende opfattelser af, hvad Learning Design er. Dette skyldes på den ene side en tilsvarende divergens i den internationale forskning og praksis, der har inspireret udviklingen i Danmark; og på den anden side at Learning Design er blevet integreret med den allerede eksisterende pædagogiske forskning og praksis i dansk kontekst. I denne artikel til jubilæumsnummeret af LOM redegør vi for tre hovedtilgange inden for Learning Design i dansk sammenhæng: "Pedagogical patterns", "Underviseren som designer" og "Didaktisk design". De tre tilgange er eksemplificeret ved hjælp af i alt fire cases fra videregående uddannelsesinstitutioner i Danmark. Vi argumenterer for, at der på tværs af de tre tilgange er seks kendetegn, der gør sig gældende: Inddragelse og operationalisering af pædagogisk teori, Undervisere som aktive og bevidste designere i en designproces, Fokus på de studerendes læring, Inddragelse af designredskaber, Bæredygtighed samt Teknologi $i$ undervisningen.
\end{abstract}




\section{Introduktion}

Denne artikel udspringer af en faglig interesse for begrebet Learning Designs anvendelse i en dansk sammenhæng samt en øget brug af Learning Design-tilgange inden for undervisningsudvikling. Vi ser imidlertid også, at der er divergerende opfattelser af, hvordan Learning Design skal forstås og anvendes.

I 2016 blev der i Tidsskriftet Læring og Medier (LOM) udgivet hele 28 artikler om Learning Design, hvor der bl.a. var fokus på både den teoretiske kontekst og praktiske implementering i Danmark (jf. LOM nr. 15 og nr.16). Allerede på daværende tidspunkt var Learning Design ved at vinde indpas i den danske undervisningskultur. Dog viste en undersøgelse både ligheder og forskelle $\mathrm{i}$, hvordan begrebet Learning Design anvendtes i forhold til de fokuseringer, der er i international sammenhæng (Buus et al., 2016). Undersøgelsen viste således, at en tredjedel af institutionerne anvendte Learning Design som en tilgang til undervisningsudvikling, og at det internationale fokus på teknologi som faktor i undervisningen også gjorde sig gældende her. Et andet vigtigt fokuspunkt i international sammenhæng er imidlertid bæredygtighed af designs, forstået som at de skal kunne deles og genbruges i andre kontekster. Dette var ikke særlig fremtrædende i det danske perspektiv. Samtidig viste artiklerne i de to udgivelser en til tider forvirrende bred anvendelse af begrebet Learning Design både teoretisk og metodisk. Dette har yderligere skærpet vores interesse for at undersøge og præcisere begrebet i dansk og international sammenhæng.

Intentionen med denne artikel er derfor at give en sammenfattende og præciserende beskrivelse af den fokusering, udvikling og forståelse af Learning Design, der gennem tiden har dannet sig i Danmark og internationalt. Vi peger på tre hovedtilgange og identificerer en række gennemgående karakteristika for Learning Design på tværs af disse. Fokuseringen er illustreret ved fire cases fra danske uddannelsesinstitutioner: Københavns Universitet, Syddansk Universitet, VIA University College og Aarhus Universitet. De fire cases er udvalgt ud fra en maximum variation sampling-strategi (Patton, 2002), således at de samlet set illustrerer de tre hovedtilgange inden for Learning Design på professionshøjskole- og universitetsniveau samt repræsenterer forskellige institutionelle kontekster med hver sin tilgang til undervisningsudvikling. Da der for en række af begreberne ikke findes veletablerede oversættelser, har vi valgt at bibeholde de engelske betegnelser for disse for ikke selv at bidrage til forvirringen på området.

\section{Hovedtilgange inden for Learning Design}

Som designteoretiker Heskett påpeger, har ordet "design" mange betydninger (Heskett, 2002). Betydningerne henviser til forskellige aspekter af menneskelig formgivning af materiale: formgivningsprocessen, prototypen/planen for en formgivning samt det resulterende produkt af en formgivningsproces. Hertil kommer udpegning af formgivningsfeltet som et fagligt domæne oprindeligt som (del af) håndværk og arkitektur, i modsætning til fx landbrug og minedrift, hvis materialebrug ikke centrerer sig om formgivning.

Learning Design er tilsvarende et felt, der helt grundlæggende beskæftiger sig med at give form til læringsmuligheder, og hvor man med rimelighed kan tale om proces, prototype/plan og produkt (Dohn \& Hansen, 2016; 2018a). Forskere inden for feltet prioriterer ofte disse betydninger forskelligt, idet deres fokus varierer fra det mere procesorienterede til det mere produktorienterede. Der findes således ikke én fælles definition af konceptet (Dobozy \& Cameron, 2018), men en række udbredte forståelser og definitioner, der fokuserer på Learning Design som enten et produkt (artefakt), en designproces eller en undervisningsudviklingsmetodologi.

Eksempelvis definerer Agostinho Learning Design som et produkt i form af en repræsentation af en undervisningspraksis: 


\begin{abstract}
"A learning design is a representation of teaching and learning practice documented in some notational form so that it can serve as a model or template adaptable by a teacher to suit his/her context." (Agostinho, 2006, p. 3)
\end{abstract}

Mens blandt andre Conole (2013) samt Mor og Craft (2012) definerer Learning Design som en proces, hvor nye undervisningspraksisser bliver udviklet:
"LD [sic] is the act of devising new practices, plans of activity, resources and tools aimed at achieving particular educational aims in a given situation" (Mor \& Craft, 2012, p. 86).

Eftersom Learning Design typisk er kendetegnet ved en systematisk og faciliteret praksis med aktiv inddragelse af undervisere samt med brug af designmetoder og -værktøjer til at understøtte undervisningsudvikling og implementering, kan Learning Design også betragtes som en egentlig undervisningsudviklingsmetodologi (Conole, 2013; Cross et al., 2011; Godsk, 2018). At sætte lighedstegn mellem Learning Design og en dokumenteret undervisningspraksis (produkt-tankegangen) er således en overforsimpling, der risikerer at overse vigtige processuelle og metodologiske aspekter af tilgangen. Denne overforsimpling optræder i øvrigt ofte ved anvendelsen af den fordanskede term "læringsdesign".

Feltet kompliceres yderligere af, at der er divergerende bud på, hvilken type produkt formgivningsprocessen er rettet imod: redskaber til læring (ofte IT-programmer som sproglæringsprogrammer og Matematik i Måneby eller Learning Management Systemer (LMS) som Lektio eller Blackboard), ressourcer for læring (eksempelvis læringsobjekter eller fagportaler som danske-dyr.dk), pædagogiske eller didaktiske metoder (som proble-baseret læring, rollespil og flipped classroom) eller aktiviteter og praksisformer (eksempelvis gruppearbejde, studenteroplæg, forelæsninger samt brug af IT-læringsredskaber og -ressourcer). Omend det ofte anerkendes, at der er mange aspekter involveret i formgivning af læringsmuligheder (Carvalho \& Goodyear, 2014; Conole, 2013; Laurillard, 2012), er litteraturen på feltet alligevel præget af forfatternes varierende fokuseringer i forhold til disse forskellige betydninger.

Et punkt, der dog går igen, er optagetheden af, hvordan teknologier (især IT) kan inddrages konstruktivt for alle de nævnte typer produkter. Dette spørgsmål er ikke som sådan iboende i feltet - principielt kunne formgivning af læringsmuligheder diskuteres uden teknologi som særskilt fokuspunkt. I praksis har både forskere og praktikere inden for Learning Design imidlertid set det som et afgørende spørgsmål, både med henblik på at realisere de læringsmæssige potentialer teknologien har, og for at imødegå de problemstillinger, som det kan give at insistere på brug af ny teknologi, blot fordi den er tilgængelig.

Et andet vigtigt punkt på tværs af forskellige fokuseringer er den gentagne understregning af, at læringsmuligheder kan designes, men ikke den studerendes faktiske læring. Learning Design er dermed indirekte design: Som uddannelsesudvikler og underviser kan man designe for læring ved - gennem redskaber, ressourcer, metoder og aktiviteter - at understøtte, at den studerende udvikler den viden, kompetence eller færdighed, som er målet for undervisning/uddannelsen. Det er således ikke ualmindeligt, at redskaber og ressourcer til Learning Design sammenkæder aktiviteter med læringsmål, men at man samtidig erkender, at hvad den studerende faktisk lærer, opstår i situationen, ud fra hvad der konkret sker i praksis, når den studerende engagerer sig med de pågældende aktiviteter og materialer.

Feltet Learning Design bestemmes her ofte (Conole, 2013; Goodyear \& Retalis, 2010; Laurillard, 2012) i kontrast til feltet Instructional Design, der først og fremmest findes i amerikansk sammenhæng. Instructional Design antager i højere grad en lineær, forudsigelig en-til-en sammenhæng mellem de læringsmuligheder og -materialer, der tilbydes den studerende, og dennes faktiske læring (Briggs et al., 1991; Gagné et al, 2005). I forhold til fokuseringerne på proces, plan og produkt forventer Instructional 
Design således sammenfald mellem materialer, planlagte aktiviteter og resulterende praksis ("produktet" af iværksatte planer for aktiviteter) - med baggrund i struktureret detailplanlægning af aktiviteter og den brug, der skal gøres af bestemte læringsressourcer. Disse læringsressourcer indeholder på sin side opsplittede, afgrænsede enheder af mål og indhold. Heroverfor er der inden for Learning Design grundlæggende en opfattelse af praksis (produkt) som emergent i forhold til plan.

I det følgende karakteriserer vi tre hovedtilgange inden for Learning Design, udpeger central litteratur for hver af dem og giver eksempler på deres brug fra dansk uddannelsessammenhæng. For hver af tilgangene pointerer vi deres primære fokuseringer i forhold til punkterne proces, prototype og produkt samt peger på, hvilke af de mulige typer af produkter (redskaber, ressourcer, metoder, aktiviteter og praksisformer) de især ser formgivningsprocessen rettet imod. Tilgangene er ikke skarpt afgrænsede fra hinanden, og nøglepersoner fra én tilgang har ofte inspireret personer fra andre. I flere tilfælde har enkeltpersoner bidraget til mere end én tilgang som følge af feltets udvikling og/eller den gradvise udvikling af deres egen position.

\section{Pedagogical patterns-tilgangen}

Historisk set har Learning Design sit udspring i denne tilgang. Grundidéen er, at undervisnings- og uddannelsespraksis byder på en række tilbagevendende situationer og problemer, og at adresseringen af disse situationer/løsningen på disse problemer må kunne beskrives som et "pedagogical pattern" ("pædagogisk mønster"), der er delbart. Eksempelvis er cooperative learnings strukturering af gruppearbejdsroller og -processer et bud på et pattern til løsning af problemet: "Hvordan kan gruppearbejde struktureres, så alle studerende deltager konstruktivt?" Fokus for denne tilgang er således udvikling af produkter i form af metoder og aktiviteter - eller rettere patterns for disse - hvilket ofte i praksis også har involveret udvikling af redskaber og ressourcer til understøttelse af disse metoder og aktiviteter.

Inspirationen for tilgangen er arkitekturteoretikeren Alexanders arbejde med udvikling af patterns inden for arkitekturen. Han beskriver patterns som:

\footnotetext{
"...a problem which occurs over and over again in our environment and then describes the core of the solution to that problem, in such a way that you can use this solution a million times over, without ever doing it the same way twice" (Alexander et al., 1977, p. x).
}

Alexanders idé var at udvikle et designsprog for arkitektur, således at patterns for større enheder ( $\mathrm{fx}$ et hus) kunne sammensættes af patterns for mindre enheder ( $\mathrm{fx}$ veranda, stue, værelse, køkken, bad, trappe osv.), der igen kunne sammensættes af mindre enheder ( $\mathrm{fx}$ væg, gulv, ornament osv.). Designsproget skulle således være kompositorisk, på samme måde som det naturlige sprog er kompositorisk.

Goodyear introducerede denne tilgang til uddannelsestænkning i en række tekster skrevet alene og sammen med andre (Goodyear et al., 2004; Goodyear, 2005; Goodyear \& Retalis, 2010). Tilgangen præsenteres som en måde at operationalisere pædagogisk teori og praktiske erfaringer på. I tråd med Alexanders idé, har Goodyear således fokus på at lave et pædagogisk designsprog bestående af pedagogical patterns, hvor simple patterns kan bygges sammen som byggeklodser til mere komplekse patterns. Hans oprindelige forslag var, at "Kursus" eller "Uddannelse" kunne være det mest overordnede pattern, sammensat af kursuselementer, der igen sammensættes af patterns for opgaver, aktiviteter, samarbejdsformer, redskabsbrug osv. Antologien Technology-enhanced Learning - Design Patterns and Pattern Languages (Goodyear \& Retalis, 2010) indeholder en række kapitler, der er inspireret af Goodyears tænkning og præsenterer Learning Designs med fokus på at kvalificere læring gennem inddragelse af teknologi. Flere af kapitlerne diskuterer endvidere forskellige former for pædagogisk designsprog. 
En variant af pedagogical patterns-tilgangen er IMS Learning Design (IMS LD) (IMS Global Learning Consortium [IMS], 2003), der satte særligt fokus på udviklingen af et teknisk sprog til at beskrive læringsdesigns. IMS LD er et såkaldt meta-sprog baseret på XML, hvilket i denne sammenhæng vil sige, at det tilbyder et maskinlæsbart sprog til at beskrive bl.a. læringsaktiviteter, læringsobjekter, roller og deres indbyrdes strukturer (IMS, 2003). For at omsætte IMS Learning Designs til reelle læringsaktiviteter og -materialer for studerende, skal XML-koderne omsættes ved hjælp af en såkaldt Learning Design “engine”. Et eksempel på en sådan engine er CopperCore udviklet ved Open University i Holland, der integreres direkte i et LMS (Koper \& Tattersall, 2010; Vogten et al., 2006). Omend det er let at få øje på fordelene $\mathrm{i}$ at have et teknisk sprog til at beskrive læringsaktiviteter på tværs af institutioner og kurser, har tilgangen alligevel haft svært ved at finde fodfæste, og de seneste opdateringer af IMS LD og CopperCore var i hhv. 2003 og 2009. Learning Activity Management System (LAMS) er derimod stadig under udvikling. Det er udviklet på Macquarie University i kølvandet af og baseret på IMS LD men har et særligt fokus på at tilbyde et let anvendeligt IT-værktøj til at understøtte undervisernes design og repræsentation af læringsaktiviteter. LAMS muliggør en direkte integration til gængse LMS'er ved hjælp af Learning Tools Interoperability-standarden (LTI).

Andre projekter har arbejdet med at beskrive Learning Designs som helt konkrete pedagogical patterns, uden dog at samle dem i et pædagogisk designsprog. Eksempler findes i Mor et al. (2014), hvori præsenteres Learning Designs under fire hovedtemaer: Learner centred design, Learning communities, Social media and learner interaction in social spaces og Assessment and feedback. Hvert Learning Design beskrives også i et design-narrativ, der ekspliciterer, hvordan designet opstod/blev udledt af praksis. Endvidere beskrives der for hvert Learning Design et scenario, der illustrerer, hvordan designet kan bruges i andre sammenhænge.

Endelig bør nævnes Laurillards udvikling af en generisk pædagogisk model, The Conversational Model, kaldet således for at understrege vigtigheden af læring som en dialogisk proces mellem underviser og studerende. Modellen beskriver studerendes læreproces som variationer over forskellige underviser- og studenteraktiviteter (Laurillard, 2002) og kan bruges til at analysere, hvordan teknologi medierer og understøtter disse aktiviteter. Ligeledes kan den bruges til at klassificere forskellige pædagogiske metoder, læringsaktiviteter og praksisformer. I den forstand fungerer den som et overordnet abstrakt pattern til indplacering af mere konkrete pedagogical patterns (Laurillard, 2002; 2012).

Problemstillinger for Learning Design forstået som produkt belyses af Falconer og Littlejohn (2009) i forbindelse med en sammenfatning af resultater fra projektet Mod4L, som var et led i rammeprojektet Design for Learning under UK Joint Information Systems Committee (JISC), 2006. De peger på fem problemstillinger:

* En spænding i formål mellem design af “eksekverbare” designs (der kan sættes direkte i gang i undervisningen med henblik på studerendes læring) og "inspirationsdesigns" (der kan inspirere underviseren). Problemet viste sig i projektet at være, at eksekverbare designs sjældent virkede inspirerende på underviserne, der derfor valgte ikke at eksekvere dem.

* Granularitet: Jo mindre enhed for et pedagogical pattern ( $\mathrm{fx}$ en opgave), jo lettere er det at genanvende, men jo mere kræver det af underviseren, der vil genanvende, i forhold til at sammenstykke en undervisningsgang og i sidste ende et helt kursus. På den anden side: jo større enhed for et pedagogical pattern, jo mere skal genanvendelsessituationen ligne den oprindelige.

* Der er forskellige bud på karakteristik af Learning Design i form af egenskaber, der gør den genanvendelig - og det er diskutabelt, hvilke(n) der er de(n) mest anvendelige.

* Fællesskab: I forlængelse af den sidste problemstilling, er det vigtigt at kende den sammenhæng af mennesker, som Learning Design skal genanvendes i, for at kunne give de rigtige - ikke for mange og ikke for få - metaoplysninger. 
* Produkt versus proces. Fokus på Learning Design som genanvendeligt produkt har tendens til at skjule den ofte forholdsvis store grad af konkret tilpasning - dvs. den proces - der er involveret i den faktiske genanvendelse.

Sidstnævnte problemstilling omkring inkludering af processen er særligt i fokus i underviseren som designer-tilgangen beskrevet $i$ afsnittet nedenfor af samme navn. Ved denne tilgang spiller underviseren en mere aktiv rolle som designer af læringsmulighederne og er således også med til at udvikle, tilpasse og kontekstualisere designprodukter. Omend undervisere også kan være aktivt involveret i designprocessen i pedagogical patterns-tilgangen som illustreret i nedenstående case, er deres rolle her dog alligevel en anden. I stedet for at underviserne hver især formgiver designs til specifikke kontekster og kursusafholdelser ved hjælp af pædagogiske modeller og lignende, kommer forudidentificerede patterns til at spille en styrende rolle i formgivningen og afholdelsen af undervisningen. Learning Design er således i høj grad præget af en design som produkt-tankegang. Fokus bliver på repræsentation og deling af detaljerede designs med de fordele og problematikker, der bl.a. er forbundet med høj granularitet, varierende genanvendelighed i forskellige kontekster og begrænset ejerskab.

\section{Case 1: Pedagogical patterns på Københavns Universitet}

På Københavns Universitet (KU) blev der i 2013-2016 igangsat et udviklingsprojekt med det formål at identificere pedagogical patterns på forskellige fakulteter på KU. I projektet blev underviserne inviteret til at dele deres erfaringer med online og blended læringsforløb, for på den baggrund at arbejde med pedagogical patterns-tilgangen inden for Learning Design. Samtidig var identificeringen af pedagogical patterns med til at konceptualisere det, som underviserne måske allerede gjorde for at understøtte de studerendes læring med teknologi (Neutzsky-Wulff et al., 2016). Projektet havde således samme grundantagelse som pedagogical patterns-tilgangen: at der må være en række tilbagevendende undervisningssituationer, hvortil der kan identificeres et design (dvs. et "pattern"), som med fordel kan deles og genbruges i udviklingen af fremtidig undervisningspraksis. Casen er derfor også et eksempel på Learning Design-praksis, hvor produkt-tankegangen er dominerende i forhold til proces-tankegangen.

Ud fra dialog og en skitsering af de pedagogical patterns, som de enkelte undervisere fremlagde, blev deres patterns sammenholdt på tværs for at kunne identificere et fælles rammeværktøj til at beskrive og videreudvikle dem. Efterfølgende blev endnu en workshop afholdt, hvor inviterede undervisere designede deres undervisningsforløb med brug af det fælles rammeværktøj for dermed at få et helhedsorienteret fælles perspektiv på designet af online og blendede undervisningsforløb på KU.

Projektets udviklede rammeværktøj og de identificerede pedagogical patterns bidrog til en synliggørelse af fælles potentialer og udfordringer i undervisningen. En sådan synliggørelse var medvirkende til, at underviserne opnåede en oplagt mulighed for sparring på tværs af fagligheder og fakulteter. Dette bidrog til, at de kunne forbedre det Learning Design, der lå til grund for undervisningsforløbet, så det understøttede de studerendes læring bedre. Dog gav projektet anledning til nogle opmærksomhedspunkter, der er værd at nævne. I tråd med de førnævnte problemstillinger ved Learning Design (Falconer \& Littlejohn, 2009), viste projektet, at det ikke var nemt at opskalere og inddrage flere undervisere på grund af det community of practice (Wenger, 1998), som underviserne indgik i. Dette udfordrer idéen om at kunne genbruge pedagogical patterns. Yderligere viste projektet, at konkrete patterns bliver meget komplekse, hvis de skal udtrykkes i et teknisk sprog.

I flere af artiklerne i LOM nr. 16 bliver de enkelte undervisningsscenarier udfoldet og belyst ud fra pedagogical patterns-tilgangen (Chuang et al., 2016; Harker-Schuch et al., 2016; Henriksen et al., 2016; Neutzsky-Wulff et al., 2016; Overgaard et al., 2016). 


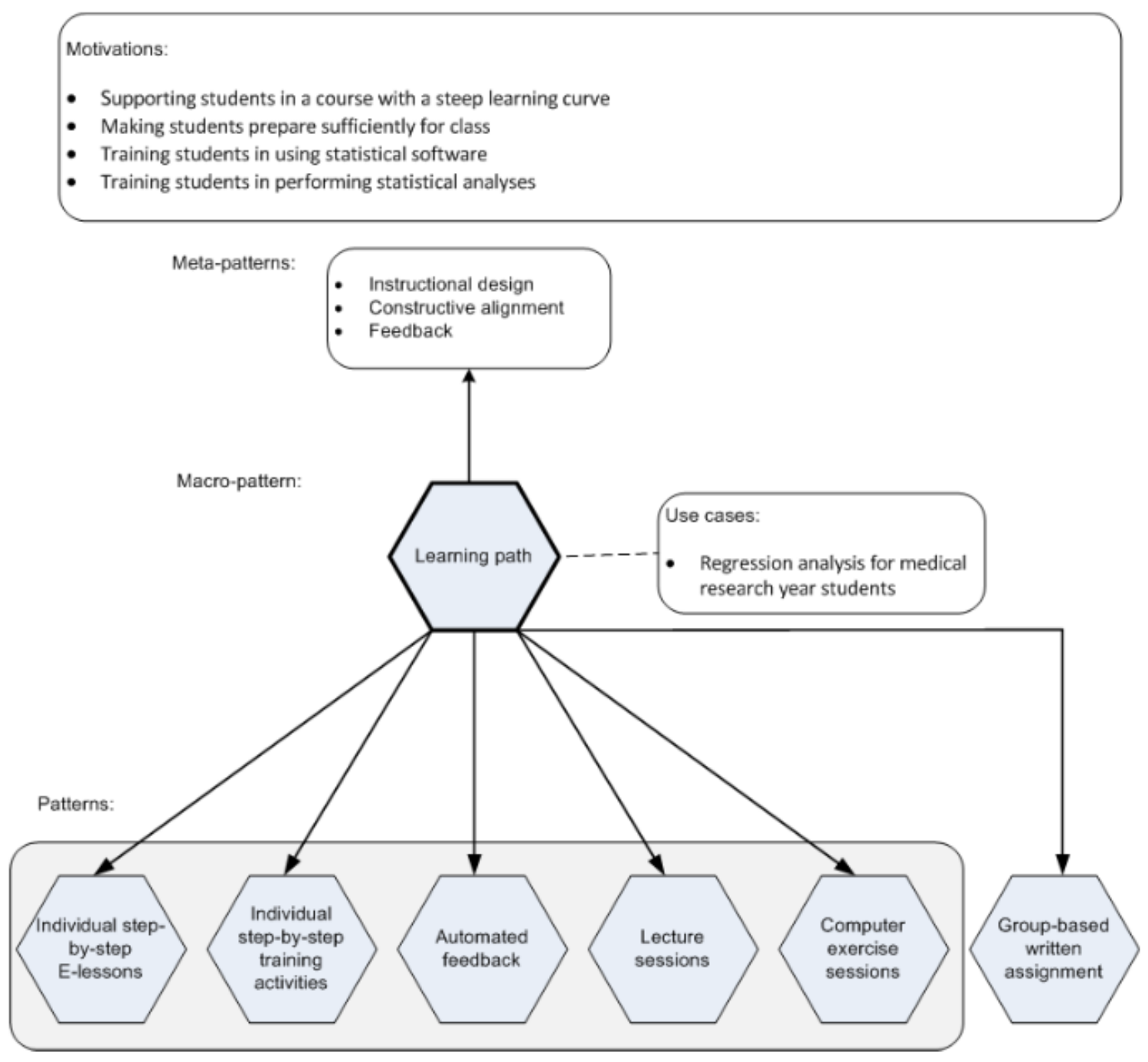

Figur 1. Illustration af et meta-pattern ved Københavns Universitet (Neutzsky-Wulff et al., 2016).

Ovenstående figur (Figur 1) illustrerer et meta-pedagogical pattern på KU. I tråd med Laurillards (2012) tilgang, hvor de enkelte patterns er specificeret yderligere i læringsaktiviteter og understøttende ressourcer, er der forskellige variationer af fx patterns og meta-patterns på KU (Neutzsky-Wulff et al., 2016). Tilgangen til Learning Design ud fra design patterns gør det muligt at involvere undervisere på et mere aktivt og bevidst grundlag. Som casen illustrerer, giver tilgangen endvidere en struktureret inddragelse af pædagogiske teorier, idet disse indgår i udviklingen af de konkrete patterns.

\section{Underviseren som designer-tilgangen}

Underviser som designer-tilgangen tager afsæt $\mathrm{i}$, at genanvendelse kræver kontekstualisering og derfor i væsentlig forstand indebærer nyanvendelse. Fokus er på processen med underviseren som den, der formgiver læringsmuligheder. Det er således helt centralt for tilgangen, at underviseren får redskaber (i form af modeller, workshops, toolkits, erfaringsudveksling mv.) til at varetage denne rolle. Redskaberne operationaliserer pædagogiske teorier på forskellig vis. Eksempelvis kan modeller og toolkits have iboende pædagogiske principper, som underviserne henter inspiration fra i løbet af designprocessen, hvilket hjælper dem til egenhændigt at kvalificere deres undervisningspraksis pædagogisk. Redskaberne kan også have form af fx underviserworkshops faciliteret af undervisningsudviklere, hvori pædagogisk begrundede værktøjer, skabeloner, modeller osv. inddrages efter behov. Underviserworkshops kan endvidere finde sted i en mere pædagogisk induktiv form, hvor den pædagogiske teori ikke nødvendigvis 
er prædefineret ved hjælp af modeller og toolkits, men hvor kvalificeringen sker gennem aktiviteter og teoretisk informerede refleksioner i løbet af workshoppen.

Tilgangen benytter sig således også af designprodukter som modeller eller strukturerende rammer (frameworks). Hensigten med sådanne designprodukter er, at de kan inspirere underviseren i designprocessen, snarere end at skulle bruges direkte som Learning Design til studerendes læring. Laurillards Conversational Framework nævnt ovenfor kan også anvendes på denne måde.

Det teoretiske grundlag for underviseren som designer-tilgangen udfoldes i Laurillards seneste bog, Teaching as a Design Science fra 2012 såvel som i Conoles Designing for Learning in an Open World fra 2013. Laurillard argumenterer således for, at undervisning er en designvidenskab, der ligesom ingeniørvidenskaberne og arkitektur har til formål at ændre verden til det bedre, for undervisnings vedkommende at gøre det muligt for studerende at udvikle deres viden og kompetencer. Pointen er på den ene side, at formgivningen må forholde sig til den konkrete situation, og at mange løsninger kan være rigtige, men at der på den anden side også er bedre og dårligere måder at gribe undervisning an på. Helt centralt for Laurillard er det, at undervisere gennem systematisk bearbejdning af deres undervisererfaringer - af relationen mellem deres design af undervisning, deres pædagogiske praksis og de studerendes læring - kan opbygge en videnskabelig vidensbank om, hvad der virker og hvorfor. Som hun siger:

\begin{abstract}
"Teaching is a design science in the sense that its aim is to keep improving its practice, in a principled way, building on the work of others... Teachers must be able to enact design science as part of their professional practice; therefore they need the means to do it - to be able to articulate and share their pedagogic practice, the outcomes they achieved, and how these outcomes related to the elements of their design." (Laurillard, 2012, pp. 8-9).
\end{abstract}

I bogen tilbyder hun netop sit Conversational Framework som bud på sådanne "means" - dvs. som planlægnings- og refleksionsværktøj, der kan systematisere ekspliciteringen og delingen af design, pædagogisk praksis og udkommet heraf.

Conole på sin side definerer Learning Design med disse ord:

\begin{abstract}
"It is a methodology for enabling teachers/designers to make more informed decisions in how they go about designing learning activities and interventions, which is pedagogically informed and makes effective use of appropriate resources and technologies. This includes the design of resources and individual learning activities right up to curriculum-level design. A key principle is to help make the design process more explicit and shareable" (Conole, 2013, pp. 7-8).
\end{abstract}

Conole ser således først og fremmest Learning Design som en undervisningsudviklingsmetodologi, der sætter underviseren i stand til at varetage designprocessen. For at støtte designprocessen såvel som målet for processen - den pædagogiske praksis og de studerendes læring - angår Learning Design også sekundært design af alle de forskellige typer produkter nævnt ovenfor: redskaber, ressourcer, metoder, aktiviteter og praksisformer. Og dette gør det, både i forhold til designprocessen (fx IT-værktøjer, modeller og metoder til at understøtte designprocessen samt bestemte aktiviteter som workshops) og i forhold til den pædagogiske praksis (redskaber, ressourcer, didaktiske metoder, aktiviteter og praksisformer, der understøtter læringsprocessen).

Som nævnt introduceredes Learning Design som pedagogical patterns i høj grad gennem Goodyears Alexander-inspirerede arbejde. Helt fra begyndelsen har Goodyear imidlertid også haft fokus på underviseren som designer: Hans motivation for at udvikle pedagogical patterns var netop at stille ressourcer til rådighed for "the teacher engaged in educational design" (Goodyear, 2005, p. 92). Præmissen var for ham den problemstilling, som Falconer og Littlejohn (2009) pegede på med afsæt i Mod4Ls empiriske projekter: at genanvendelse kræver kontekstualisering, således at der stadig er en 
designproces tilbage for underviseren, også når denne er blevet forsynet med pedagogical patterns. I de seneste år er Goodyears fokus blevet endnu mere koncentreret på underviseren som designer-tilgangen, idet hans designorienterede forskning centrerer sig dels om selve designprocessen, dels om at opstille modeller på et højere abstraktionsniveau til brug i designprocessen. Her har han sammen med Carvalho udviklet Activity-Centred Analysis and Design (ACAD) (Carvalho \& Goodyear, 2014; Goodyear et al., 2016). Denne ekspliciterer tre dimensioner for Learning Design: epistemisk design (design af opgaver), socialt design (design af sociale roller, som de studerende forventes at indtage, mens de arbejder med opgaverne) og sæt design (design af fysiske og virtuelle ressourcer og læringsmiljøer, som understøtter arbejdet med opgaverne). Dimensionerne kan anvendes både i designprocessen og i efterfølgende analyse af de aktiviteter og praksisformer, der bliver resultatet. Det er et centralt punkt for Goodyear, at aktiviteter er emergente, idet de udspiller sig i de studerendes reaktion på de tre dimensioner af design. Læring er derfor også emergent, da læring opstår som følge af det, den studerende faktisk gør, ikke som følge af det, læreren havde planlagt, at den studerende skulle gøre. Dette er essensen i Goodyears understregning af, at læring ikke kan designes, men kun designes for - og at Learning Design derfor er indirekte.

\section{Case 2: STREAM-initiativet ved Aarhus Universitet}

STREAM-initiativet ved Aarhus Universitet er et eksempel på underviser som designer-tilgangen. På baggrund af en strategisk satsning på teknologi i undervisningen på Aarhus Universitet (2011) med henblik på at modernisere undervisningen og øge de studerendes læring, påbegyndte Faculty of Science and Technology (ST) deres Learning Design-initiativ i 2012. Hensigten med Learning Design-initiativet var dels at kunne håndtere udviklings- og implementeringsarbejdet på systematisk og effektiv vis, dels at kunne støtte underviserne $\mathrm{i}$ at træffe pædagogisk velinformerede valg $\mathrm{i}$ forbindelse med deres integration af teknologi i undervisningen.

I første omgang - dvs. i 2012 - blev Learning Design inkluderet som et fast tema på fakultetets adjunktpædagogikum (Bjælde et al., 2015; Godsk, 2013). Året efter blev et egentligt Learning Designinitiativ igangsat bestående af et toolkit med en pædagogisk model (et "framework", Conole \& Fill, 2005), STREAM (Figur 2; Godsk, 2013) til at guide undervisere og undervisningsudviklere i deres design af undervisning med teknologi samt en teknisk værktøjskasse bestående af videoproduktionsfaciliteter og support til opsætning af aktiviteter i universitetets LMS.

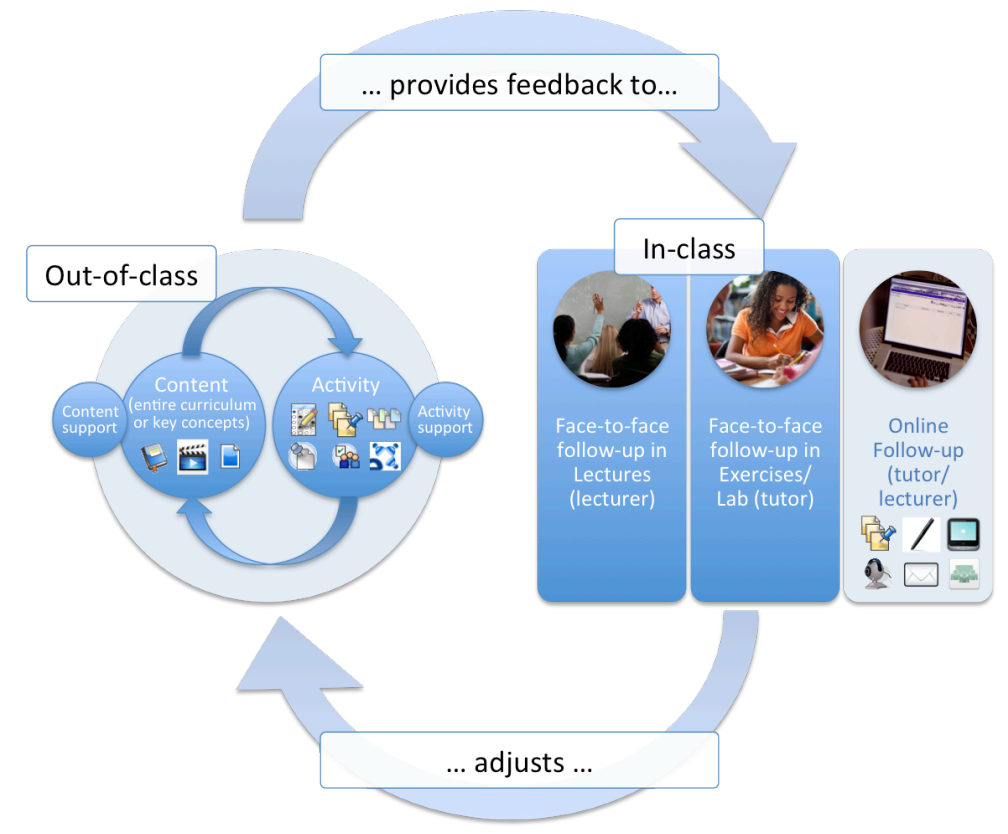

Figur 2. STREAM-modellen. 
I 2015 blev STREAM adopteret og videreudviklet af Faculty of Health med henblik på kvalificeret ibrugtagning af det nyanskaffede LMS (Godsk \& Hansen, 2016). I 2018 blev Learning Design gjort til de facto-undervisningsudviklingsmetodologi på ST samtidig med, at initiativet blev udvidet til også at inkludere designworkshops for undervisere og en systematik til at evaluere effekt og effektivitet af designs. Endelig blev en letvægtsudgave af learning analytics til at understøtte undervisernes praksis introduceret (Godsk et al., 2018). I skrivende stund betyder det, at mindst 100 kursusafholdelser på ST allerede er guidet af Learning Design, og 200 flere er under omlægning.

Omend underviserne præsenteres for ovenstående model, er den ikke obligatorisk for deres formgivningen af undervisning, og der præsenteres også en række andre cases og pædagogiske modeller til inspiration. På basis af dette og andet identificerer underviserne prioriterede kvaliteter for deres undervisning ved hjælp af kort og skabeloner samt skitserer deres undervisning ved hjælp af et webbaseret design-værktøj, LDTool (University of Wollongong, 2019). Underviserne spiller således en afgørende og aktiv rolle i udviklingen af deres undervisning. I modsætning til Case 1, hvor Learning Design-produktet var i fokus, har denne case et større fokus på processen. Hensigten er dog stadig at få undervisere til at dele og genbruge designs. Case 1 havde imidlertid et klart formål om at udvikle designs til genbrug, hvorimod man i Case 2 var mere interesseret $\mathrm{i}$ at få undervisere til at dele designs med henblik på inspiration og vidensdeling.

\section{Case 3: Learning Design i Efter- og videreuddannelserne på VIA}

På VIA University College (VIA) blev der i 2018 inviteret til designworkshops inden for Learning Design på hele området inden for Efter- og videreuddannelse (EVU). Ligesom på AU, var disse designworkshops en del af et strategisk træk fra ledelsen for at styrke den digitale dimension i EVU.

Intentionen var at invitere underviserne til at deltage i en designproces i undervisningsteams med henblik på en ny- eller gentænkning af deres undervisning. På ledelsesniveau blev det besluttet, at det var obligatorisk for alle medarbejdere inden for alle fagområder i EVU at deltage i disse workshops. Deltagelse fordrede endvidere, at underviserne forberedte sig individuelt forud for designworkshoppen ved hjælp af udleveret online materiale. Som en del af det online materiale var der et inspirationskatalog med fokus på didaktisk tilgang til forskellige teknologiske værktøjer, som underviserne kunne læne sig op ad i designprocessen. Samtidig blev workshoppen faciliteret af designkonsulenter med pædagogisk, didaktisk og teknologisk baggrundsviden samt erfaring inden for afholdelse af Learning Designworkshops.

Arbejdet med designprocessen gav anledning til en pædagogisk dialog i underviserteamet, hvilket nogle underviserteams aldrig reelt havde haft før. Learning Design-workshoppen havde desuden fokus på, hvordan der kunne integreres mere digital tilrettelagt undervisning og brug af teknologiske ressourcer i undervisningen. VIA introducerede samtidig et nyt LMS, hvilket afstedkom et yderligere fokus på at integrere de teknologiske funktionaliteter, som dermed blev stillet til rådighed. Fra ledelsens side blev der desuden stillet det krav til designet, at underviserne skulle transformere én tilstedeværelsesdag til de studerendes digitale arbejde uden tilstedeværelse af underviser.

I foråret 2018 blev der udviklet et koncept for tilrettelæggelsen af Learning Design-workshops inspireret af bl.a. en Collaborativ e-Learning Design metode (Nyvang \& Georgsen, 2007) samt Conoles taksonomiske framework (Conole, 2007). Konceptet er baseret på 5 faser, hvor der i selve designprocessen (fase 3) arbejdes med at specificere aktiviteter, ressourcer og infrastruktur. Fokus var på underviseren som designer, og det var samtidig vigtigt, at underviserne gennem designprocessen og efterfølgende havde en facilitator tilknyttet med en pædagogisk, didaktisk og teknologisk baggrundsviden (Buus, 2015). Learning Design-workshops blev gennemført i sommeren 2018 (jf. Figur 3, som et eksempel på en Learning Design-skitsering), og der blev efterfølgende fulgt op og faciliteret i efteråret 2018. 


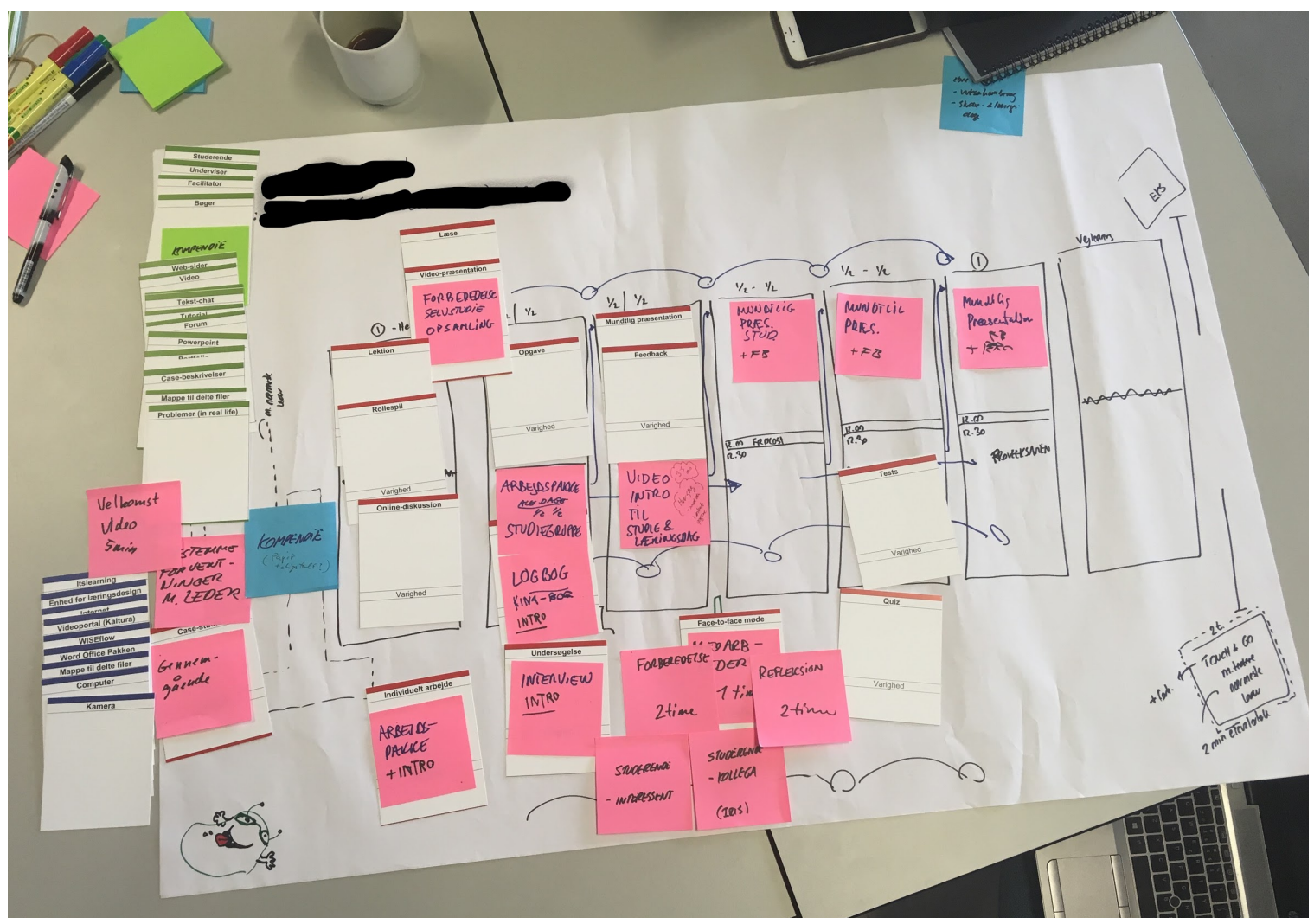

Figur 3. Learning Design udarbejdet ved en workshop på VIA.

I foråret 2019 er der i IT og Digitaliseringsafdelingen på VIA udarbejdet et opfølgende koncept med konkret fokus på de tekniske funktioner i VIAs LMS, men med et pædagogisk-didaktisk fokus på aktiviteter og anvendelse. Intentionen er fremadrettet at integrere Learning Design-tilgangen på hele VIA i forbindelse med en reorganisering og strategisk satsning på pædagogisk-didaktisk digitalisering inden for alle fagområder. Ligesom Case 2 har fokus i Case 3 været på processen i anvendelsen af undervisere som designer-tilgangen; dog stadig med en intention om, at underviserne făr udarbejdet et produkt, som kan indgå i deres undervisningspraksis. På sigt er intentionen endvidere at afholde interne konferencer, hvor underviserne præsenterer deres effektive designs for derigennem at kunne inspirere hinanden og sikre en vis bæredygtighed af initiativet.

\section{Didaktisk design-tilgangen}

Som indikeret med casene ovenfor har både pedagogical patterns-tilgangen og underviseren som designer-tilgangen været repræsenteret i dansk regi med klar inspiration fra - ofte i direkte forlængelse af - det internationale miljø. Imidlertid er feltet Learning Design i dansk-skandinavisk sammenhæng også ofte blevet reformuleret som Didaktisk design. Dette er sket i kraft af den uddannelsesteoretiske kontinentaleuropæiske tradition, som dansk-skandinavisk pædagogisk forskning og praksis har været del af i hvert fald siden det 19. århundrede. Denne tradition har fokus på didaktik forstået som en først og fremmest teoretisk disciplin ("undervisningslære”), der angår undervisningens hvad og hvem i en dannelsesoptik. Hvor de angelsaksisk inspirerede Learning Design-tilgange behandlet ovenfor sætter fokus på undervisningens hvormed (redskaber og ressourcer) og hvordan (metoder samt aktiviteter og praksisformer), er det centrale spørgsmål i den teoretiske dannelsesdidaktik hvilket indhold, der skal vælges, for at understøtte elevens dannelse som selvstændigt individ og som deltager i kultur og samfund. Endvidere ses underviseren som autonomt ansvarlig for konkret besvarelse af disse spørgsmål for al sin undervisning - traditionelt gives der ikke et fastsat detaljeret curriculum eller læringsmål, som kan give svaret herpå. Som udtrykt af Künzli i en sammenligning af kontinentaleuropæiske og angelsaksiske forståelser af uddannelsesteori: 
"The 'Didaktiker' does not begin by asking how a student learns, how a pupil can be led towards a body of knowledge, nor does he or she ask what a student should be able to do or know, but instead asks wherein the character-forming significance of the knowledge and skills lies which a culture has at its disposal" (Künzli, 2000, p. 46)

Traditionelt har det været omdiskuteret, om undervisningens praktiske og metodiske side - det, som de angelsaksisk inspirerede Learning Design-tilgange primært angår - overhovedet hørte med til didaktikkens felt. Klafki er en nutidig eksponent for den opfattelse, at det ikke hører med (Klafki, 1991).

Didaktisk design-tilgangen sammentænker teoretisk den kontinentaleuropæiske uddannelsesteoretiske tradition med især underviseren som designer-tilgangen. Derfor medtager tilgangen naturligt nok den praktiske og metodiske side (i lighed med mange nyere didaktikere, bør det understreges, fx Heimann, 1976; Hiim \& Hippe, 1993; Jank \& Meyer, 2005). Fra den kontinentaleuropæiske tradition overtages imidlertid det synspunkt, at spørgsmål om indhold og mål er helt centrale. På lavere uddannelsesniveauer (grundskole og gymnasium) forstås mål og indhold - i tråd med det kontinentaleuropæiske afsæt - typisk i bredere dannelsesmæssig betydning end faglige læringsmål. På det universitære uddannelsesniveau træder egentlig almendannelsestænkning i baggrunden (som en opgave, der hører de lavere uddannelsesniveauer til), således at fokus bliver på uddannelsens mål og indhold, både specifikt fagfaglige og mere generelle som akademisk literacy, kritisk refleksion og employabilitet.

Tilgangen følger også som oftest den kontinentaleuropæiske tradition i at se læreren som den, der autonomt har ansvaret for at besvare spørgsmål om mål og indhold (inden for rammerne af en studieordning). Det er derfor heller ikke overraskende, at tilgangen i højere grad har sammentænkt traditionen med underviseren som designer-tilgangen end med pedagogical patterns-tilgangen. Inspirationen er gået på, hvordan underviseren kan støttes $\mathrm{i}$ at træffe didaktiske valg $\mathrm{i}$ en uddannelsesverden præget af de nye udfordringer og muligheder, som bl.a. gives med ny teknologi, skærpede dokumentationskrav, målstyret undervisning, samfundsrelevans og krav om undervisningsdifferentiering (Dohn \& Hansen, 2016). Som Gynther udtrykker behovet for at koble designtænkning sammen med traditionel didaktisk tænkning:

"Designbegrebet ... skal sætte fokus på, at undervisning i skolen konstrueres eller designes ud fra nogle bestemte didaktiske overvejelser, altså formes, placeres og lanceres til brug i en specifik undervisningskontekst, i et specifikt fag til nogle specifikke elever." (Gynther, 2010, p. 18).

Dohn og Hansen (2016; 2018a) laver en kritisk gennemgang af forskellige positioner inden for didaktisk design-tilgangen med afsæt i de forskellige betydninger af design nævnt ovenfor: proces, prototype/plan, produkt. Endvidere tilføjer de (med inspiration fra Heskett, 2002) endnu en betydning, realiseringen af en bevidst intention. Denne betydning sammenfatter proces-, prototype- og produktbetydningerne i én (idealiseret) proces: realiseringen af en prototype til et endeligt produkt gennem en designproces. De påpeger, at de fleste inden for tilgangen forstår didaktisk design som undervisningsplan (forstået som en prototype til realisering i praksis), der udvikles af den enkelte underviser til den konkrete situation (hvorfor der ikke er tale om et pedagogical pattern). Gynthercitatet ovenfor udtrykker dette synspunkt, og det findes tilsvarende udtrykt fx i Hansen (2012). Også Levinsen og Sørensen (2011) understreger denne betydning, men tilføjer "samt løbende modifikation af det forventede i mødet med den fremvoksende konkrete praksis. Didaktiske designs kan derfor alene forstås og udvikles gennem udøvet praksis” (Levinsen \& Sørensen, 2011, p. 11). Med denne tilføjelse søger de at tage højde for praksis' emergens - at praksis ikke kan determineres, men opstår i reaktionen på design - som også Goodyear pointerede. En anden variant findes hos Dohn, der definerer didaktisk design på denne måde: 


\begin{abstract}
"Vi anvender begrebet didaktisk design til at dække den overordnede undervisnings- eller forløbsorganisering, der begrunder og sammentænker undervisningens enkelte elementer og læringsaktiviteter i forhold til målene sat for forløbet og det konkrete indhold, der skal behandles." (Dohn, 2011, p. 72).
\end{abstract}

Med denne definition vil Dohn dels fastholde betydningen undervisningsplan som det, der begrunder og sammentænker undervisnings- og forløbsorganiseringen. Dels vil hun pege på, at den emergente praksis kan have en anden, implicit, intentionalitet end den, underviseren bevidst har intenderet - en form for bourdieusk praksislogik (Bourdieu, 1977; 1990). Som når undervisere intenderer - og eksplicit hævder at lave - aktiverende undervisning, men i praksis ender med at effektuere et informationsformidlingsdesign igennem uafbrudt forelæsning. Denne situation er desværre ikke ukendt (Postareff, 2010).

Afslutningsvis bør det nævnes, at enkelte teoretikere med fokus på de lavere uddannelsestrin har taget centreringen om det konkrete klasseværelse og de konkrete elever så langt, at de har hævdet, at didaktisk design ikke kun angår underviserens planlægning, men også den enkelte elevs egen formgivning af sin læreproces (Gynther, 2010; Selander \& Svärdemo-Åberg, 2008). Der er også eksempler på teoretikere, der har forstået didaktisk design som design af ressourcer og læringsmiljø (Fibiger, 2002; Selander \& Svärdemo-Åberg, 2008). Sammenfattende for alle disse variationer er imidlertid understregningen af den intentionalitet, der er specifik for didaktik: den iboende sammenhæng mellem indhold, mål og aktiviteter.

\title{
Case 4: Didaktisk design af kompetence-portfolioforløb på Syddansk Universitet
}

Denne case angår didaktisk design af et kompetenceportfolioforløb. Casen er beskrevet i LOM nr. 17 i en artikel, hvis mål er at bidrage til udviklingen af portfoliopædagogikken gennem introduktion af begrebet "portfoliokoncept", forstået som Learning Design (Hansen \& Dohn, 2017). Her beskrives casen som ét eksempel på et portfoliokoncept. Den er yderligere beskrevet i Hansen \& Dohn (2018b; 2019, in press). Den konkrete setting for casen er faget It-didaktik i organisationer på cand.it-uddannelsen i Webkommunikation, Syddansk Universitet (SDU). Det didaktiske design er iterativt udviklet og gennemprøvet i seks gennemløb af faget; første gang med kun fem studerende, de øvrige fem gange med 25-35 studerende.

Som nævnt ovenfor har didaktisk design på det universitære niveau sjældent et almendannelsesfokus, men dog ofte et bredere sigte end blot fagets læringsmål. Dette er også tilfældet her. Formålet med kompetenceportfolioforløbet er således ligeligt at støtte de studerende i udviklingen af akademiske kompetencer, stimulere deres engagement i faget og skabe øget employabilitet for dem - i ét med opfyldelsen af fagets læringsmål. Dette gøres gennem formuleringen af en kompetenceprofil, som faget retter sig imod, med fem centrale kompetencer. Hver af disse kompetencer er der efterfølgende formuleret en portfolioopgave til, hvor både form og indhold er fastsat ud fra den konkrete kompetence. Portfolioopgaverne - eller rettere: hvad de studerende har behov for at lære for at kunne lave opgaverne - bestemmer herefter, hvilke temaer, der dækkes i undervisningen, hvilke tekster der læses, og hvordan der arbejdes med dem i tilstedeværelsesundervisningen. Dette illustrerer på den ene side den tætte sammenhæng mellem mål, indhold og aktiviteter, som er kendetegnende for didaktisk design-tilgangen. På den anden side illustrerer det fokus på de studerendes læring og underviserens rolle som aktiv og bevidst designer ud fra operationaliseret pædagogisk teori (her om portfoliopædagogik), som tilgangen har tilfælles med de andre Learning Design-tilgange. Som argumenteret i Hansen og Dohn (2017), er portfoliokonceptet (udvikling af kompetenceprofil med tilhørende opgaver og tilrettelæggelse af undervisning derefter) delbart og genbrugeligt også i andre fag. 
Konkret er kompetenceprofilen It-didaktisk designer $i$ organisationer, og de fem kompetencer er organisationsanalytisk kompetence, didaktisk planlægningskompetence, praktisk undervisningskompetence, evalueringskompetence og kritisk udviklingskompetence. Formen på opgaverne varierer fra skriftlig opgave (til adressering af organisationsanalytisk kompetence) til rollespilsafprøvning af undervisningssession på holdet (til adressering af praktisk undervisningskompetence). Portfolioopgaverne (inkl. optagelser af rollespilsafprøvningerne) samles i en digital portfolio på SDU's LMS. Kompetenceprofilen synliggør fagets erhvervsrelevans for de studerende, og de enkelte portfolioopgaver støtter dem $\mathrm{i}$ at transformere faglig viden til professionsrettede kompetencer. Det er herigennem, at spørgsmålet om employabilitet adresseres.

\section{Learning Designs karakteristika}

På trods af de forskellige fokuseringer, tilgange til og definitioner af Learning Design er det muligt at udlede en række generiske karakteristika for Learning Design-praksisser. Disse karakteristika gør sig gældende for alle tre tilgange til Learning Design og kan ses illustreret i de fire præsenterede cases.

\section{Inddragelse og operationalisering af pædagogisk teori}

Learning Design er kendetegnet ved, at pædagogisk teori inddrages i designet af undervisningspraksis. Den pædagogiske teori er typisk gjort operationel ved hjælp af forskellige former for pædagogiske modeller, frameworks og patterns samt forskellige hjælpemidler, toolkits og designværktøjer, således at også undervisere, der ikke har en pædagogisk baggrund, kan basere deres praksis på relevant, pædagogisk teori. Inddragelsen af pædagogisk teori kan ske på såvel deduktiv som induktiv vis. Fx er undervisernes brug af pedagogical patterns i Case 1 og STREAM-modellen i Case 2 eksempler på en pædagogisk helt eller delvis deduktiv tilgang, hvor den pædagogiske teori allerede er omsat til en model, som underviseren tilrettelægger sin undervisning efter. Learning Design-praksis kan også være pædagogisk induktiv, fx når underviserne selv udtænker deres designs uden foruddefinerede pædagogiske modeller som eksempelvis ved workshops på VIA i Case 3 eller i udvikling af portfoliokonceptet i Case 4.

\section{Undervisere som aktive og bevidste designere i en designproces}

Undervisere er aktivt involveret i undervisningsudviklingen og træffer selv de pædagogiske valg og/eller implementerer designet i egen undervisningspraksis. Underviserne søges således også gjort bevidst om rollen som designer for læring, ikke kun formidler af pensum. En sidegevinst ved undervisernes aktive rolle som designer er det ejerskab over undervisningen og det kendskab til formen, det bevirker. I modsætning til undervisere, der i høj grad baserer deres undervisning på præfabrikerede undervisningsmaterialer og -aktiviteter, vil undervisere, der designer egen praksis (eventuelt faciliteret af andre), have et klart billede af, hvordan materialer, aktiviteter osv. skal indgå i undervisningen. Ved alle fire cases er underviserne involveret i implementeringen af designet i undervisningspraksis, omend graden af aktiv rolle i udviklingen af selve designet varierer.

\section{Fokus på de studerendes læring}

Learning Design har et eksplicit mål og ambition om, at man kan designe for studerendes læring. Der er således ikke kun fokus på de studerendes aktivitet og/eller de involverende materialer, men i høj grad også på de studerendes læring, læringsproces og læringsudbytte (Conole, 2013; Sims, 2013). Dvs. undervisere bliver ansporet til at lade de studerendes læringsproces være rygraden i deres undervisning - i modsætning til fx undervisning styret af materialer og ugeskema. Portfoliokonceptet i Case 4 illustrerer, hvordan man inden for didaktisk design-tilgangen kan tilrettelægge undervisning med dette 
fokus. LDTool fra University of Wollongong (2019) tilbyder endvidere et konkret redskab til understøttelse af en sådan tilrettelæggelse, idet Learning Designs her repræsenteres som en sekvens af læringsaktiviteter. LDTool er sammen med Case 2 eksempel på, hvorledes underviseren som designertilgangen forsøger at støtte underviseren i at designe for de studerendes læring. Endelig støttes underviserne også i pedagogical patterns-tilgangen i at designe for de studerendes læring. Dette gøres typisk ved at kæde en serie patterns sammen med et eller flere konkrete læringsmål. Eksempelvis har serien af patterns illustreret i Figur 1, Case 1 til formål at introducere til statistisk analyse (anført som "motivations").

\section{Inddragelse af designredskaber}

Learning Design involverer en vifte af redskaber til at støtte designprocessen. Der sondres typisk mellem redskaber, ressourcer samt metoder til at støtte underviserne i deres pædagogiske valg og værktøjer til at repræsentere designs. Redskaber og metoder til at støtte de pædagogiske valg kan eksempelvis bestå i designworkshops, frameworks, skabeloner, pædagogiske modeller, toolkits, design patterns og exemplars. Foruden selve formen af disse redskaber består den primære forskel i, hvor pædagogisk foruddefineret de er. Conole og Fill (2005) beskriver denne række af redskaber som et kontinuum, der spænder fra frameworks i den ene ende, hvori kun de pædagogiske rammer er defineret, til design patterns og skabeloner i den anden, der meget præcist beskriver de studerendes aktiviteter, brugen af materialer osv. Ligeledes tager værktøjerne til repræsentation af designs mange former og spænder over bl.a. papirskabeloner til at notere sekvenser af læringsaktiviteter, som det er tilfældet i Collaborative ELearning Design Method (CoED) (Georgsen \& Nyvang, 2007) samt Open Universitys Learning Design Initative (OULDI, 2019), IT-forfatterværktøjer som CompendiumLD (2019) og LDTool, der gør det muligt at skitsere designs online, til LAMS og IMS (2003), der kan integreres med LMS, hvorved skitser direkte kan omsættes til læringsaktiviteter. Fælles for de omtalte værktøjer er, at de ikke har en erklæret, underliggende pædagogik, men derimod tilstræber en pædagogisk neutralitet, således at de kan benyttes til at repræsentere en bred vifte af designs.

\section{Bæredygtighed}

Learning Design har et iboende ønske om at tilbyde et sprog til at repræsentere, dele og genbruge undervisningspraksisser (Conole, 2013; Dalziel et al., 2016, Koper \& Tattersall, 2010; Mor \& Winters, 2007). Dette kommer bl.a. til udtryk i de føromtalte værktøjer til repræsentation af designs samt pædagogiske skabeloner, modeller og patterns til at informere praksis. Særligt Larnaca-deklationen fra 2012 omtaler Learning Design som et "notational system", der, ligesom noder kan udtrykke musik, kan fungere som et:

"general descriptive framework that could describe many different types of teaching and learning activities" (Dalziel et al., 2016, p. 15)

Hensigten er dermed også at skabe en bæredygtig tilgang til undervisningsudvikling i både ressourceog holdbarhedsmæssig forstand, hvor velfungerende praksisser deles og genbruges samt ultimativt bidrager til kvalitetssikring og en effektiv praksis (Buus et al., 2016; Godsk, 2018).

\section{Teknologi i undervisningen}

Selvom det ikke altid fremgår eksplicit, er hensigten med Learning Design (næsten altid) at udvikle/transformere undervisning i retning af teknologi-støttet, blended eller online learning ("digitalisering") på effektiv vis (Conole, 2013; Goodyear, 2005). Dette formål gør sig også gældende i de fire cases, som artiklen har eksemplificeret Learning Design-tilgangene med. 


\section{Konklusion}

Som bl.a. LOM nr. 15 og 16 og de fire præsenterede cases bevidner, er Learning Design et praksis- og forskningsfelt i vækst. LOM nr. 15 og 16 bevidner imidlertid også, at der, ligesom i udlandet, endnu ikke er etableret én fælles og udbredt definition af begrebet, men at feltet derimod er præget af en række divergerende forståelser og misforståelser. Dette forsøger denne artikel at adressere ved at samle de mest gængse forstålser af Learning Design, præsentere de tre overordnede tilgange til feltet samt identificere seks generiske karakteristika for Learning Design-praksisser. Forståelser, tilgange og praksisser er endvidere illustreret ved hjælp af fire cases fra fire forskellige videregående uddannelsesinstitutioner i Danmark.

Det er vanskeligt at sige noget entydigt om årsagen til interessen for Learning Design, men de fire inkluderede cases sandsynliggør, at den til dels skyldes de seks identificerede karakteristika. Herunder i særlig grad at Learning Design kan benyttes til at introducere teknologi i undervisningen på systematisk og effektiv vis, at udviklingsprocessen er ressource- og holdbarhedsmæssig bæredygtig, at Learning Design kan støtte vidensdeling kolleger imellem, samt at Learning Design tillader aktiv involvering af undervisere. Learning Design kan således også være en effektiv undervisningsudviklingsmetodologi til at adressere den digitaliseringsdagsorden, som har præget de videregående uddannelser i Danmark de seneste 12-15 år. Et vigtigt fokusområde for fremtidig Learning Design-forskning og -praksis er således at undersøge Learning Designs potentialer som undervisningsudviklingsmetodologi, herunder om den kan skabe bedre begrundet, kritisk reflekteret og effektiv undervisning med teknologi. Ligeledes synes det vigtigt at undersøge, hvorvidt nogle undervisningspraksisser egner sig mere til Learning Design end andre i dansk sammenhæng.

\section{Referencer}

Agostinho, S. (2006). The use of a visual learning design representation to document and communicate teaching ideas. Proceedings of the 23rd annual ascilite conference: Who's learning? Whose technology?

Alexander, C., Silverstein, M., Ishikawa, S., Jacobson, M., Fiksdahl-King, I., \& Angel, S. (1977). A pattern language: towns, buildings, construction. New York: Oxford University Press.

Bjælde, O. E., Caspersen, M. E., Godsk, M., Hougaard, R. F., \& Lindberg, A. B. (2015). Learning design for science teacher training and educational development. Globally connected, digitally enabled. Proceedings ascilite 2015.

Boud, D., Ajjawi, R., Dawson, P., \& Tai, J. (2018). Developing Evaluative Judgement in Higher Education: Assessment for Knowing and Producing Quality Work. Milton: Routledge Ltd.

Bourdieu, P. (1977). Outline of a theory of practice, translated by R. Nice. Cambridge: Cambridge University Press.

Bourdieu, P. (1990). The logic of practice. Stanford: Stanford University Press.

Briggs, L. J., Gustafson, K. L., \& Tillman, M. (1991). Instructional design: Principles and applications. Englewood Cliffs, New Jersey: Educational Technology Publications.

Buus, L. (2015). The learning potentials and challenges when integrating Web 2.0 in a problem-based learning approach (Aalborg University). Ph.d.-afhandling. Hentet fra https://aauforlag.dk/shop/phd-udgivelse/phdby-lillian-buus.aspx

Buus, L., Godsk, M., \& Hachmann, R. (2016). Learning design-pædagogiske og didaktiske modeller for undervisningsudvikling, kvalitetssikring og effektivisering på de videregående uddannelser. Tidsskriftet Læring og Medier (LOM), 9(15), https://doi.org/10.7146/lom.v9i15.104445

Carvalho, L., \& Goodyear, P. (Eds.). (2014). The architecture of productive learning networks. New York: Routledge.

Chuang, Victoria Jae, Alejandro Ceballos, Helle Bundgaard, Peter Furu, Henrik Bregnhøj, Inez Harker-Schuch, and Christian Bugge Henriksen (2016): "Understanding the Dynamics of Online Learning Communities; Experiences from Three University Courses.” Tidsskriftet Læring Og Medier (LOM) 9, no. 16 (November 4, 2016). https://doi.org/10.7146/lom.vgi16.24412.

CompendiumLD learning design software (2019). Retrieved from http://compendiumld.open.ac.uk/

Conole, G. (2013). Designing for learning in an open world. New York: Springer. 
Conole, G., \& Fill, K. (2005). A learning design toolkit to create pedagogically effective learning activities. Journal of Interactive Media in Education, 2005(1). Retrieved from http://oro.open.ac.uk/11725/

Conole, G. (2007). "Describing Learning Activities -Tools and Resources to Guide Practice.” In Rethinking Pedagogy for a Digital Age: Designing and Delivering E-Learning, 81-91. New York : London: Routledge.

Cross, S., Masson, A., O’Donnell, C., \& Galley, R. (2011). Identifying and changing key curriculum design practices. Retrieved February 14, 2019, from http://www.onlineconference.net/jisc/content2011/masson/Viewpoints OULDI FINAL.ppt

Dalziel, J., Conole, G., Wills, S., Walker, S., Bennett, S., Dobozy, E., Cameron, L., Badilescu-Buga, E., \& Bower, M. (2016). The Larnaca Declaration on Learning 169

Design - 2013. In J. Dalziel (Ed.). Learning design: Conceptualizing a framework for teaching and learning online. New York: Routledge.

Dobozy, E, \& Cameron, L. (2018). Editorial: Special issue on learning design research: Mapping the terrain. Australasian Journal of Educational Technology, 34(2). https://doi.org/10.14742/ajet.4390

Dohn, N. B. (2011). Interaktive muligheder og udfordringer i web 2.o. In J. Asmussen (Ed.), Digitalt dansk: Mediedidaktik 2.0 (pp. 71-88). København: Academica.

Dohn, N. B., \& Hansen, J. J. (2016). Begrebet "didaktisk design" - et kritisk overblik over betydninger. In N. B. Dohn \& J. J. Hansen (Eds.), Didaktik, design og digitalisering (pp. 43-63). Frederiksberg: Samfundslitteratur.

Dohn, N. B., \& Hansen, J. J. (2018). Design in educational research - clarifying conceptions and presuppositions. In N. B. Dohn (Ed.), Designing for learning in a networked world (pp. 25-47). Abingdon: Routledge.

Gagné, R. M., Wager, W. W., Golas, K. C., \& Keller, J. M. (2005). Principles of instructional design (5. ed.). Belmont, CA: Thomson/Wadsworth.

Georgsen, M., \& Nyvang T. (2007). “Collaborative E-Learning Design Method (CoED).” E-Learning Lab Publication Series. E-Learning Lab: Aalborg University.

Godsk, M. (2013). STREAM: a Flexible Model for Transforming Higher Science Education into Blended and Online Learning. In T. Bastiaens, \& G. Marks (Eds.), Proceedings of World Conference on E-Learning in Corporate, Government, Healthcare, and Higher Education 2013 (pp. 722-728). Chesapeake, VA: AACE. Retrieved from http://www.editlib.org/p/114927.

Godsk, M. (2018). Improving STEM Undergraduate Education with Efficient Learning Design. EdD Thesis. The Open University. Retrieved from http://oro.open.ac.uk/5.504.5/

Godsk, M. \& Hansen, J. S. (2016). Learning design som systematisk alternativ til one-hit wonders implementering af educational it i de våde fag på Aarhus Universitet. Tidsskriftet Læring og Medier (LOM), 9(15), https://doi.org/10.7146/lom.vgi15.23127

Godsk, M., Hougaard, R. F., \& Bennedsen, J. (2018). Learning Design, Learning Analytics, and Learning Management Systems. In Proceedings of ICERI2018 Conference. Retrieved from https://pure.au.dk/portal/files/136128183/1474.pdf

Godsk, M., Hougaard, R. F., \& Lindberg, A. B. (2013). Teaching Online Teaching Online: Seven Pedagogical Principles for Teacher Training. In E-Learn: World Conference on E-Learning in Corporate, Government, Healthcare, and Higher Education (pp. 95-104). Association for the Advancement of Computing in Education (AACE).

Goodyear, P. (2005). Educational design and networked learning: Patterns, pattern languages and design practice. Australasian journal of educational technology, 21(1), 82-101.

Goodyear, P., Avgeriou, P., Baggetun, R., Bartoluzzi, S., Retalis, S., Ronteltap, F., \& Rusman, E. (2004). Towards a pattern language for networked learning. Paper presented at the Networked Learning 2004, Lancaster.

Goodyear, P., Carvalho, L., \& Dohn, N. B. (2016). Artefacts and activities in the analysis of learning networks. In S. Bayne, M. de Laat, T. Ryberg, \& C. Sinclair (Eds.), Research, Boundaries and Policy in Networked Learning (pp. 93-110). New York: Springer.

Goodyear, P., \& Retalis, S. (Eds.). (2010). Technology-enhanced learning: Design patterns and pattern languages. Rotterdam: Sense Publishers.

Gynther, K. (Ed.) (2010). Didaktik 2.o: læremiddelkultur mellem tradition og innovation. København: Akademisk Forlag.

Hansen, J. J. (2012). Dansk som undervisningsfag. Perspektiver på design og didaktik. København: Dansklærerforeningens forlag.

Hansen, J. J., \& Dohn, N. B. (2017). Portfoliokoncepter-med caseportfolioen og kompetenceportfolien som eksempel. Tidsskriftet Læring og Medier (LOM), 1O(17). https://doi.org/10.7146/lom.v10i17.25854

Hansen, J. J., \& Dohn, N. B. (2018). Design principles for learning in simulated social practices. In N. B. Dohn (Ed.), Designing for Learning in a Networked World (pp. 214-231). Abingdon: Routledge. 
Hansen, J. J., \& Dohn, N. B. (2019, in press). Designing for mediational transition and learning through simulation - a task analysis of knowledge transformation. In N. B. Dohn, S. B. Hansen, \& J. J. Hansen (Eds.), Designing for situated knowledge transformation. Abingdon: Routledge.

Harker-Schuch, Inez Estelle, Henrik Bregnhøj, Victoria Jae Chuang, Peter Furu, Ingelise Andersen, and Christian Bugge Henriksen (2016). Facilitating Online Project Collaboration - New Directions for Learning Design. Tidsskriftet Læring Og Medier (LOM) 9, no. 16 (November 4, 2016). https://doi.org/10.7146/lom.vgi16.24411.

Heimann, P. (1976). Didaktik als Theorie und Lehre. In P. Heimann (Ed.), Didaktik als Unterrichtswissenschaft (pp. 142-167). Stuttgart: Ernst Klett Verlag.

Henriksen, C. B., Henrik Bregnhøj, Susanne Rosthøj, Alejandro Ceballos, Henrik Kaas, Inez Harker-Schuch, Ingelise Andersen, Søren Larsen, and Michael May, (2016). Technology Enhanced Peer Learning and Peer Assessment. Tidsskriftet Læring Og Medier (LOM) 9, no. 16 (November 4, 2016). https://doi.org/10.7146/lom.v9i16.24415.

Heskett, J. (2002). Toothpicks and logos: Design in everyday life. Oxford: Oxford University Press.

Hiim, H., \& Hippe, E. (1993). Læring gjennom opplevelse, forståelse og handling: en studiebok i didaktikk. Oslo: Universitetsforlaget.

IMS Global Learning Consortium (2003). IMS Learning Design Best Practice and Implementation Guide Version 1.o Final Specification. Retrieved from https://www.imsglobal.org/learningdesign/index.html

Jank, W., \& Meyer, H. (2005). Didaktische Modelle (7. ed.). Berlin: Cornelsen Scriptor.

Klafki, W. (1991). Neue Studien zur Bildungstheorie und Didaktik : zeitgemässe Allgemeinbildung und kritischkonstruktive Didaktik (2. erw. Aufl. ed.). Weinheim: Beltz Verlag.

Koper, R., \& Tattersall, C. (Eds.) (2010). Learning Design. A Handbook on Modelling and Delivering Networked Education and Training. Berlin: Springer.

Künzli, R. (2000). German Didaktik: Models of re-presentation, of intercourse, and of experience. In I. Westbury, S. Hopmann, \& K. Riquarts (Eds.), Teaching as a reflective practice: The German Didaktik tradition (pp. 4154). Mahwah, NJ: Lawrence Erlbaum Associates.

Laurillard, D. (2002). Rethinking university teaching: a conversational framework for the effective use of learning technologies (2 ed.). London: RoutledgeFalmer.

Laurillard, D. (2012). Teaching as a design science: building pedagogical patterns for leaning and technology. New York: Routledge.

Levinsen, K. T., \& Sørensen, B. H. (2011). Fremtidsrettede kompetencer og didaktisk design. In B. Meyer (Ed.), Itdidaktisk design (8 ed., pp. 14-33). Aarhus: Institut for Uddannelse og Pædagogik (DPU), Aarhus Universitet.

Mor, Y., \& Craft, B. (2012). Learning design: reflections upon the current landscape. Research in learning technology, 20. https://doi.org/10.3402/rlt.v20io.19196

Mor, Y., Mellar, H., Warburton, S., \& Winters, N. (Eds.). (2014). Practical design patterns for teaching and learning with technology. Rotterdam: SensePublishers.

Mor, Y., \& Winters, N. (2007). Design approaches in technology-enhanced learning. Interactive Learning Environments, 15(1), 61-75. https://doi.org/10.1080/10494820601044236

Neutszky-Wulff, C., Rosthøj, S., Harker-Schuch, I., Chuang, V. J., Bregnhøj, H., Henriksen, C. B., \& May, M. (2016). A Pedagogical Design Pattern Framework for Sharing Experiences and Enhancing Communities of Practice within Online and Blended Learning. Tidsskriftet Læring Og Medier (LOM) 9, no. 16 (November 4, 2016). https://doi.org/10.7146/lom.vgi16.24414.

OULDI (2019). Open University Learning Design Initiative. Retrieved from http://www.open.ac.uk/blogs/OULDI/

Overgaard, Julie Hougaard, Jesper Bruun, Michael May, and Linda Udby (2016): "Virtual Neutron Scattering Experiments - Training and Preparing Students for Large-Scale Facility Experiments.” Tidsskriftet Læring Og Medier (LOM) 9, no. 16 (November 4, 2016). https://doi.org/10.7146/lom.v9i16.24231.

Patton, M. Q. (2002). Qualitative Designs and Data Collection (3rd edition), Thousand Oaks: Sage Publications.

Postareff, L. (2010). How do teachers' self-reports of their teaching correspond with their teaching practices? Paper presented at the International Consistorium for Educational Development, Barcelona.

Selander, S., \& Svärdemo-Åberg, E. (Eds.). (2008). Didaktisk design i digital miljö - nya möjligheter för lärande. Stockholm: Liber.

Sims, R. (2013). Design Alchemy: transforming the way we think about learning and teaching. Retrieved from http://www.slideshare.net/RoderickSims/130627-edmediainvited

University of Wollongong (2019). Home - LDTool. Retrieved from http://needle.uow.edu.au/ldt/

Vogten, H., Martens, H., Nadolski, R., Tattersall, C., Van Rosmalen, P., \& Koper, R. (2006, July). CopperCore service integration-integrating IMS learning design and IMS question and test interoperability. In Sixth IEEE 
International Conference on Advanced Learning Technologies (ICALT'o6) (pp. 378-382). IEEE. https://doi.org/10.1080/10494820701343827

Wenger, E. (1998): Communities of Practice - Learning, Meaning, and Identity. Edited by John Seely Brown and Jan Hawkins. Learning in Doing: Social, Cognitive and Computational Perspectives. New York: Cambridge University Press.

Aarhus Universitet (2011). Den Faglige Udviklingsproces. Øvrige bilag. Universitetsledelsen den. 9. marts. Retrieved November 21, 2013, from

http://medarbejdere.au.dk/fileadmin/res/fau/dok/fau bilag oevrige bilag 090311.pdf 


\section{Forfattere}

\section{Nina Bonderup Dohn}

Professor, dr.phil., ph.d.

Institut for Design og Kommunikation,

Syddansk Universitet

\section{Mikkel Godsk}

Undervisningsudvikler og leder af Media Lab, EdD

ST Learning Lab,

Aarhus Universitet

\section{Lillian Buus}

Specialkonsulent, konstitueret forskningsprogramleder, ph.d. Enheden for Læringsdesign og VIA Læring og IT VIA University College
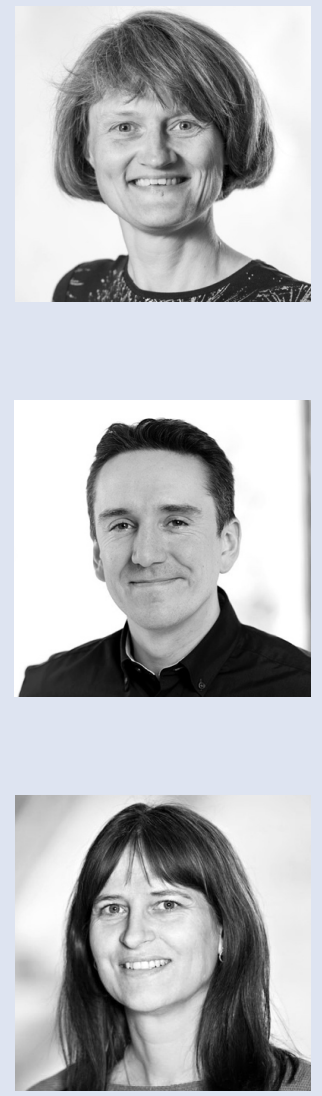